\title{
Short-term fluctuations of microbial and chemical variables during different seasons in coastal Baltic waters
}

\author{
K. Gocke, K. Kremling, C. Osterroht, A. Wenck \\ Institut für Meereskunde an der Universität Kiel, Düsternbrooker Weg 20, D-2300 Kiel, Federal Republic of Germany
}

\begin{abstract}
Short-term fluctuations of microbial, planktological and chemical variables were studied in a nearshore area of the Kiel Bight during 4 different seasons. The following mean values in January, March, June and September were found: total bacterial numbers: $0.59,0.46,1.44$ and $2.11 \times 10^{6}$ cells $\mathrm{ml}^{-1}$; maximum uptake velocity of glucose: $0.004,0.037,0.102$ and $0.127 \mu \mathrm{g} \mathrm{C} \mathrm{l}^{-1} \mathrm{~h}^{-1}$; turnover rate of glucose: $17.9,142,496$ and $265 \% \mathrm{~d}^{-1}$ Seasonal amplitude of variations in dissolved organic carbon was small. Maximum uptake velocity per bacterial cell increased by more than an order of magnitude between January and March and decreased slightly during the following seasons. Strong short-term variations of microbial parameters were detected, which did not show distinct diel rhythms. If these exist they are masked by changing hydrographical conditions.
\end{abstract}

\section{INTRODUCTION}

Many investigations of seasonal variations of bacterial numbers and activity have been performed during recent years. Due to lack of ship-time most of them could be made only with monthly or at best weekly sampling intervals even in coastal areas. Since bacteria react very quickly to changes of biotic and abiotic parameters in their environment (Rheinheimer 1985), these studies can give only a rough picture of the microbiological situation. This problem is of special importance in transitional areas like the Kiel Bight, where rapid hydrographical and biological changes occur as a common feature (Kändler 1951, Lenz 1977. Babenerd 1980).

It was therefore the aim of the present work to perform a seasonal study of microbial parameters with frequent sampling over several days, which should allow estimation of short-term variations with respect to seasonal amplitudes of bacterial numbers and activities.

\section{STUDY AREA}

The ship was anchored at a fixed station near the western coast of the Kiel Bight at a water depth of about $23 \mathrm{~m}$ (Fig. 1). The Kiel Bight is a relatively shallow part of the transitional area between the North Sea and the Baltic Sea. It is crossed by channels and deeps of a postglacially formed, and later inundated, river and lake system. The main water exchange occurs from the northwest to the southeast through the Great Belt and the Fehmarn Belt, which are connected by a channel system, from which a trough passes near the station area and runs into the Eckernförde Bay. In this region rapid movements of water masses are a common feature as indicated by fast changes in salinity (Babenerd \& Zeitzschel 1985).

\section{SAMPLING AND ANALYTICAL METHODS}

Samples were taken over a period of 2 to $3 \mathrm{~d}$ in each of the 4 seasons: 25 to $28 \mathrm{Jan}$ (winter), 15 to $18 \mathrm{Mar}$ (spring), 1 to 3 Jun (summer) 1982; and 8 to 11 Sep 1981 (autumn). Seawater from a depth of $4 \mathrm{~m}$ was continually pumped aboard ship. At $4 \mathrm{~h}$ intervals discrete subsamples were drawn for the determination of microbiological, planktological and chemical parameters.

Temperature and salinity were measured using an in situ TS-probe with precisions of $\pm 0.2 \mathrm{C}^{\circ}$ and $\pm 0.1 \times$ $10^{-3}$, respectively.

Determination of microbial activity was performed 


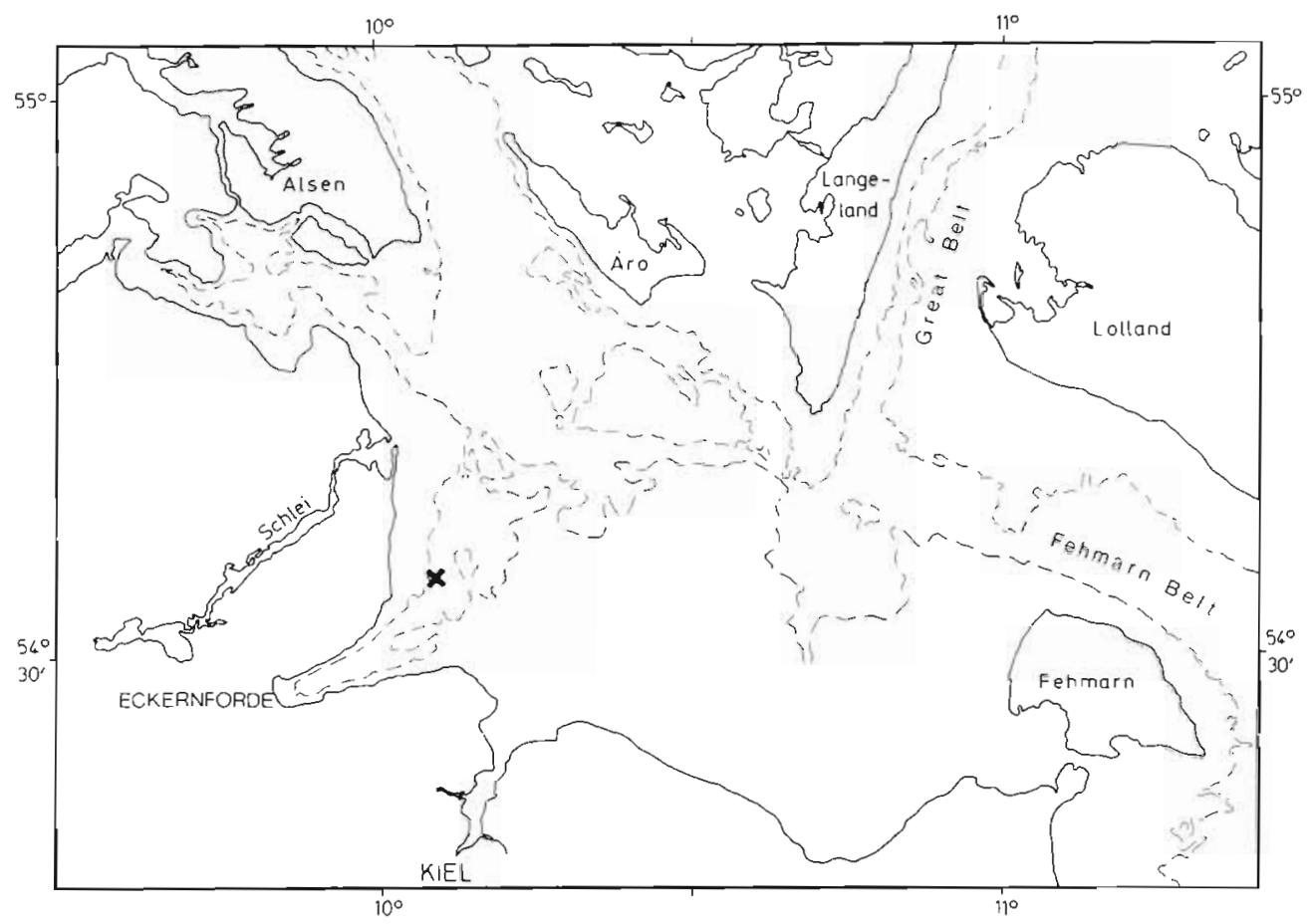

Fig. 1. Anchor station in the Kiel Bight. Broken lines indicate $20 \mathrm{~m}$ depth contour

immediately after taking the sample. Six different quantities of uniformly labelled ${ }^{14} \mathrm{C}$-glucose (Amersham-Buchler) were pipetted into water samples of 50 ml each, resulting in glucose concentrations between 0.5 and $10.0 \mu \mathrm{g}$ glucose-C $\mathrm{I}^{-1}$. Samples were incubated in the dark using a reciprocal water bath. The incubation temperature was close to the in situ temperature $\left( \pm 1 \mathrm{C}^{\circ}\right)$. Incubation times were $3 \mathrm{~h}$ in January and March and $1.5 \mathrm{~h}$ in June and September, respectively.

This method allowed measurement of the maximum glucose uptake velocity $\left(V_{\max }\right)$, the turnover time $\left(T_{t}\right)$ or turnover rate $\left(T_{r}\right)$ and the sum of the natural glucose concentration and the 'uptake constant' $\left(K_{1}+S_{n}\right)$. Since the fraction of glucose respired by heterotrophic microorganisms was not determined, the values correspond only to net uptake. The procedure, which is a modification of the method of Wright \& Hobbie (1966), is described in greater detail by Gocke (1977).

Determination of total bacterial number was performed, after staining the cells with acridine orange, by fluorescence microscopy according to the procedure outlined by Zimmermann \& Meyer-Reil (1974).

Phytoplankton carbon (PPC) was calculated by multiplying cell numbers by carbon conversion factors given by Strathmann (1967) and Elder (1979). The chlorophyll a concentration was determined by fluorescence absorption according to Liebezeit (1980).

The concentration of dissolved organic carbon (DOC) was obtained by UV-destruction (Schreurs 1978).

\section{RESULTS}

\section{Hydrographic conditions}

Fig. 2 shows the depth profiles of temperature and salinity. Mean values of these parameters at $5 \mathrm{~m}$ depth were calculated and those individual profiles are shown which fitted best to the means. The general feature of low salinity values at the surface and higher ones in the deep layer, which is typical for the study area, is clearly depicted. The resulting stratification was most pronounced during September 1981, when $\mathrm{H}_{2} \mathrm{~S}$ was also detected in the deeper layer (Ehrhardt \& Wenck 1984). Osterroht et al. (1985a) assumed that major intrusions of water masses from more distant parts of the Baltic Sea did not occur during our study periods. The changes in salinity shown in Fig. 2 however clearly indicate that local movements of water masses due to vertical mixing or advection must have taken place during the course of our measurements.

\section{Microbiological parameters}

\section{Seasonal variations}

Total bacterial numbers (TBN) were quite low during winter and early spring sampling, when only 0.59 and $0.46 \times 10^{6}$ cells $\mathrm{ml}^{-1}$ (mean values respectively) were 

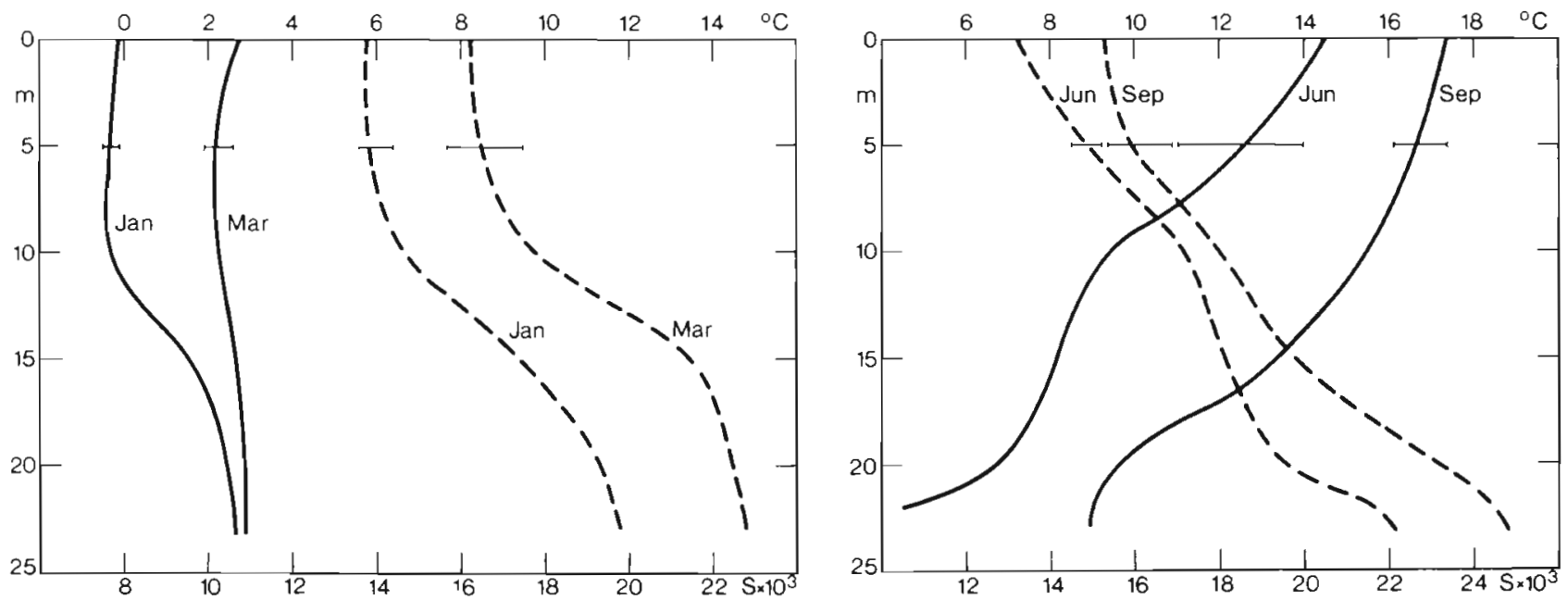

Fig. 2. Depth profiles of temperature (solid lines) and salinity (broken lines) during the 4 sampling periods. Range of the fluctuation at $5 \mathrm{~m}$ depth given as horizontal bars
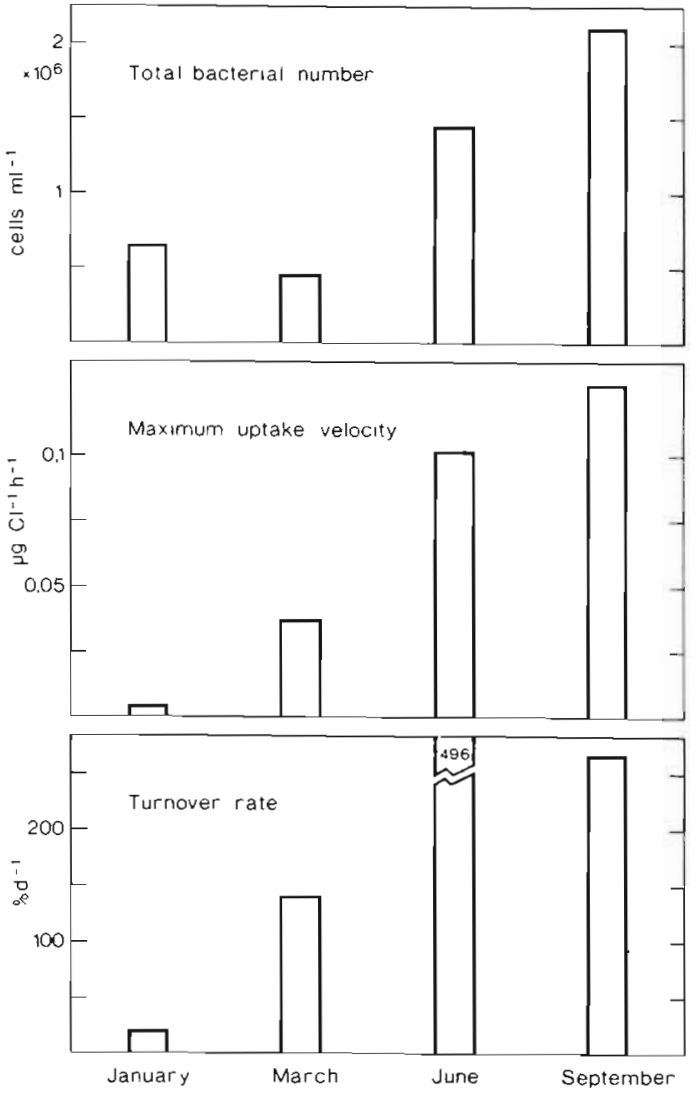

Fig. 3. Mean values of microbiological parameters

present. The numbers increased to 1.44 and $2.11 \times 10^{6}$ bacteria $\mathrm{ml}^{-1}$ during the summer and autumn stations respectively (Fig. 3). These bacterial numbers are in accordance with those previously encountered in the Kiel Bight (Zimmermann 1977). The biomass of bacteria was not determined. Judging from similar studies in the Kiel Bight (Zimmermann 1977) it may be in the range of 3 to $5 \mu \mathrm{g} \mathrm{C} \mathrm{^{-1 }}$ for winter and spring and 8 to 15 $\mu \mathrm{gC}^{-1}$ for summer and autumn.

The maximum uptake velocity of glucose ( $\left.\mathrm{V}_{\text {max }}\right)$ revealed a gradual increase from very low values around $0.004 \mu \mathrm{g} \mathrm{C} \mathrm{l}^{-1} \mathrm{~h}^{-1}$ (mean value) during January, which were near the detection limit of the method, to $0.127 \mu \mathrm{g} \mathrm{C} \mathrm{l}^{-1} \mathrm{~h}^{-1}$ in September (Fig. 3). The winter values are lower than those given by Gocke (1977) for the center of the Kiel Bight, whereas the September values are somewhat higher. Similar low values as in January were found by Gocke \& Hoppe (1982a) at the end of April in the eastern part of the Bornholm Basin just before the onset of the phytoplankton spring bloom.

Fig. 3 also shows the mean values of the turnover rates of the dissolved free glucose pool. The turnover rates rose from $17.9 \% \mathrm{~d}^{-1}$ during January, which is equivalent to a turnover time of $134 \mathrm{~h}$, to $496 \% \mathrm{~d}^{-1}$ in June. The latter value means that the turnover time of glucose would be $4.8 \mathrm{~h}$. Unlike the other parameters shown in Fig. 3, the highest value of the turnover rate was found not in autumn but in summer.

Means and extreme values of the microbial parameters, as well as those of phytoplankton carbon (PPC), chlorophyll a concentration and dissolved organic carbon, are given in Table 1. Low winter and summer values of PPC contrast with high values in March (phytoplankton spring bloom) and September. The chlorophyll a concentration shows the same tendency. The concentration of dissolved organic carbon remained relatively unaltered throughout the year with somewhat elevated values during summer and autumn. This increase in DOC may be partly due to an increase in labile organic matter derived from phytoplankton production processes and especially autolysis, which support the higher bacterial numbers and activity found during these sample periods. 
Table 1. Mean values of microbiological, planktological and chemical parameters. Values in parentheses are range or standard deviation. TBN: total bacterial number; $V_{\text {maxx }}$ : maximum uptake velocity of glucose; $T_{r}$ : turnover rate of glucose; $K_{t}+S_{n}$ : sum of uptake constant and natural concentration of glucose; PPC: phytoplankton carbon; DOC: dissolved organic carbon

\begin{tabular}{|c|c|c|c|c|c|c|c|c|}
\hline $\begin{array}{l}\text { Sampling } \\
\text { month }\end{array}$ & $\begin{array}{c}\text { TBN } \\
\left(\times 10^{6} \mathrm{ml}^{-1}\right)\end{array}$ & $\left(\mu g C 1^{-1} h^{-1}\right)$ & $\begin{array}{l}\mathrm{V}_{\max } \\
\text { per cell }\end{array}$ & $\begin{array}{c}T_{r} \\
\left(\% d^{-1}\right)\end{array}$ & $\begin{array}{c}K_{\mathrm{t}}+\mathrm{S}_{\mathrm{n}} \\
\left(\mu \mathrm{g} C \mathrm{C}^{-1}\right)\end{array}$ & $\begin{array}{c}\mathrm{PPC} \\
\left(\mu \mathrm{g} \mathrm{C} \mathrm{l}^{-1}\right)\end{array}$ & $\begin{array}{c}\text { Chlorophyll a } \\
\left(\mu g 1^{-1}\right)\end{array}$ & $\begin{array}{c}\mathrm{DOC} \\
\left(\mathrm{mg} \mathrm{C} 1^{-1}\right)\end{array}$ \\
\hline January & $\begin{array}{c}0.59 \\
(0.26-1.55)\end{array}$ & $\begin{array}{c}0.004 \\
(0.004-0.005)\end{array}$ & 6.8 & $\begin{array}{c}17.9 \\
(11.4-60)\end{array}$ & $\begin{array}{c}0.55 \\
( \pm 0.24)\end{array}$ & $\begin{array}{c}35.9 \\
(27.5-47.5)\end{array}$ & $\begin{array}{c}0.6 \\
(0.4-0.8)\end{array}$ & $\begin{array}{c}2.46 \\
(2.26-2.99)\end{array}$ \\
\hline March & $\begin{array}{c}0.46 \\
(0.21-0.70)\end{array}$ & $\begin{array}{c}0.037 \\
(0.023-0.063)\end{array}$ & 80.4 & $\begin{array}{l}142 \\
(43-250)\end{array}$ & $\begin{array}{c}0.67 \\
( \pm 0.23)\end{array}$ & $\begin{array}{c}409 \\
(322-529)\end{array}$ & $\begin{array}{l}11 \\
(5.5-16.9)\end{array}$ & $\begin{array}{c}2.43 \\
(2.08-2.84)\end{array}$ \\
\hline June & $\begin{array}{c}1.44 \\
(0.68-29.3)\end{array}$ & $\begin{array}{c}0.102 \\
(0.038-0.188)\end{array}$ & 70.8 & $\begin{array}{c}496 \\
(206-952)\end{array}$ & $\begin{array}{c}0.53 \\
( \pm 0.22)\end{array}$ & $\begin{array}{c}36.5 \\
(13.3-48.5)\end{array}$ & $\begin{array}{c}0.9 \\
(0.6-1.4)\end{array}$ & $\begin{array}{c}2.86 \\
(2.34-3.12)\end{array}$ \\
\hline September & $\begin{array}{c}2.11 \\
(1.24-2.88)\end{array}$ & $\begin{array}{c}0.127 \\
(0.082-0.164)\end{array}$ & 60.2 & $\begin{array}{c}265 \\
(138-400)\end{array}$ & $\begin{array}{c}1.22 \\
( \pm 0.30)\end{array}$ & $\begin{array}{c}307 \\
(200-534)\end{array}$ & $\begin{array}{c}13.0 \\
(7.5-19.5)\end{array}$ & $\begin{array}{c}2.88 \\
(2.75-3.10)\end{array}$ \\
\hline \multicolumn{9}{|c|}{ - $V_{\max }$ per cell $\left(10^{-12} \mu \mathrm{g} \mathrm{Ch}^{-1}\right)$} \\
\hline
\end{tabular}

\section{Short-term variations}

The reproducibility of measurement of the microbiological parameters was checked by repeating the measurements 2 or 3 times. The difference between individual values proved to be relatively small, especially in the case of the maximum uptake velocity. The parameters $\mathrm{K}_{\mathrm{t}}+\mathrm{S}_{\mathrm{n}}$ and the total bacterial number, however, show somewhat larger differences (Table 2). We conclude therefore that the observed short-term fluctuations are real and not due to inadequacies in the methods used.

During the January sampling variations in maximum uptake velocity were nearly absent in spite of pronounced fluctuations in total bacterial numbers (Fig. 4). This is probably due to the low temperature and the overall low bacterial activity. Fluctuations in the turnover rate are somewhat higher, and are even more pronounced in the case of $K_{+}+S_{n}$. This may be due to local water movements, which are also responsible for the changes in total bacterial number. On the other hand, since the method was near its application limits, the results for $T_{r}$ and $K_{t}+S_{x l}$ may suffer from somewhat larger systematic problems.

In March an increase in $V_{\max }$ occurred towards the end of sampling. This increase is also shown by the turnover rate. In contrast, the high chlorophyll a concentrations dropped somewhat towards the end of this study period. The values for $K_{t}+S_{n}$ are quite uniform except for an unusual high one at $2200 \mathrm{~h}$ on $17 \mathrm{Mar}$, which led to a drop in the turnover rate (Fig. 5).

Variations in the activity parameters $V_{\max }$ and $T_{r}$ were much more pronounced during March than January. Although the water temperature was still low, phytoplankton biomass and chlorophyll a concentrations were large and showed strong temporal fluctuations (Osterroht et al. 1985b). The changes in the
Table 2. Results of repeated measurements of the microbiological parameters. For definitions, see Table 1

\begin{tabular}{|c|c|c|c|c|c|}
\hline $\begin{array}{l}\text { Sam- } \\
\text { pling } \\
\text { date }\end{array}$ & Time & $\begin{array}{c}\text { TBN } \\
\left(\times 10^{6}\right. \\
\left.\mathrm{ml}^{-1}\right)\end{array}$ & $\begin{array}{c}V_{\max } \\
\left(\mu \mathrm{g} \mathrm{C} \mathrm{I}^{-1}\right. \\
\left.\mathrm{h}^{-1}\right)\end{array}$ & $\begin{array}{c}T_{\mathrm{r}} \\
\left(\% \mathrm{~d}^{-1}\right)\end{array}$ & $\begin{array}{c}\mathrm{K}_{t}+\mathrm{S}_{\mathrm{n}} \\
\left(\mu \mathrm{g} \mathrm{Cl}^{-1}\right)\end{array}$ \\
\hline 26 Jan & $1400 \mathrm{~h}$ & $\begin{array}{l}0.60 \\
0.63\end{array}$ & & & \\
\hline $18 \mathrm{Mar}$ & $1000 \mathrm{~h}$ & $\begin{array}{l}0.53 \\
0.45 \\
0.47\end{array}$ & $\begin{array}{l}0.053 \\
0.054 \\
0.052\end{array}$ & $\begin{array}{l}249 \\
235 \\
222\end{array}$ & $\begin{array}{l}0.47 \\
0.60 \\
0.58\end{array}$ \\
\hline & $1400 \mathrm{~h}$ & $\begin{array}{l}0.53 \\
0.46\end{array}$ & $\begin{array}{l}0.051 \\
0.053\end{array}$ & $\begin{array}{l}173 \\
188\end{array}$ & $\begin{array}{l}0.71 \\
0.68\end{array}$ \\
\hline & $1800 \mathrm{~h}$ & $\begin{array}{l}0.42 \\
0.38\end{array}$ & $\begin{array}{l}0.063 \\
0.062\end{array}$ & $\begin{array}{l}255 \\
250\end{array}$ & $\begin{array}{l}0.63 \\
0.62\end{array}$ \\
\hline 2 Jun & $1800 \mathrm{~h}$ & & $\begin{array}{l}0.052 \\
0.049\end{array}$ & $\begin{array}{l}420 \\
423\end{array}$ & $\begin{array}{l}0.30 \\
0.28\end{array}$ \\
\hline 3 Jun & $1400 \mathrm{~h}$ & & $\begin{array}{l}0.188 \\
0.185\end{array}$ & $\begin{array}{l}615 \\
554\end{array}$ & $\begin{array}{l}0.74 \\
0.82\end{array}$ \\
\hline 11 Sep & $0600 \mathrm{~h}$ & & $\begin{array}{l}0.133 \\
0.132\end{array}$ & $\begin{array}{l}363 \\
328\end{array}$ & $\begin{array}{l}0.90 \\
0.97\end{array}$ \\
\hline
\end{tabular}

microbial parameters could be an indirect response to the variations of the phytoplankton. No correlation was found, however, between planktological and microbiological variables.

In June (Fig. 6) a surprisingly high $\mathrm{V}_{\max }$ and $\mathrm{T}_{\mathrm{r}}$ with marked fluctuations occurred in the presence of only a small phytoplankton biomass, which showed only minor changes during the study period. Here the $V_{\max }$ and the total bacterial number were significantly correlated $(p<0.1 \%)$. A correlation between $V_{\max }$ and $T_{r}$ could not be found. There is, however, a certain similarity in the shape of the curves during the second half of the period (Fig. 6). 

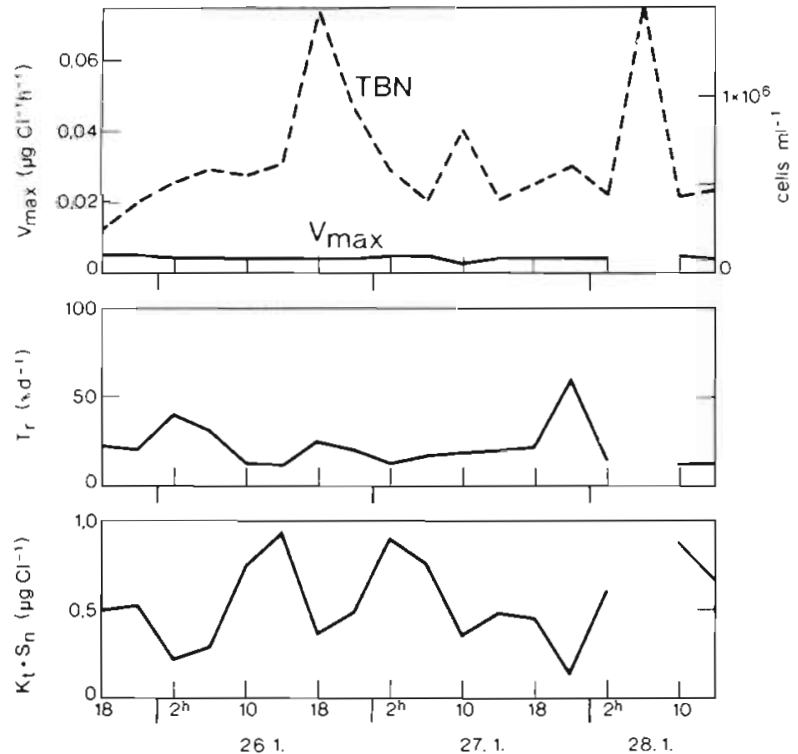

Fig. 4. Short-term fluctuations of microbiological parameters in January. TBN: total bacterial number; $V_{\max }$ : maximum uptake velocity of glucose; $T_{r}$ : turnover rate of glucose; $K_{t}+$ $\mathrm{S}_{\mathrm{n}}$ : sum of uptake constant and natural concentration of glucose
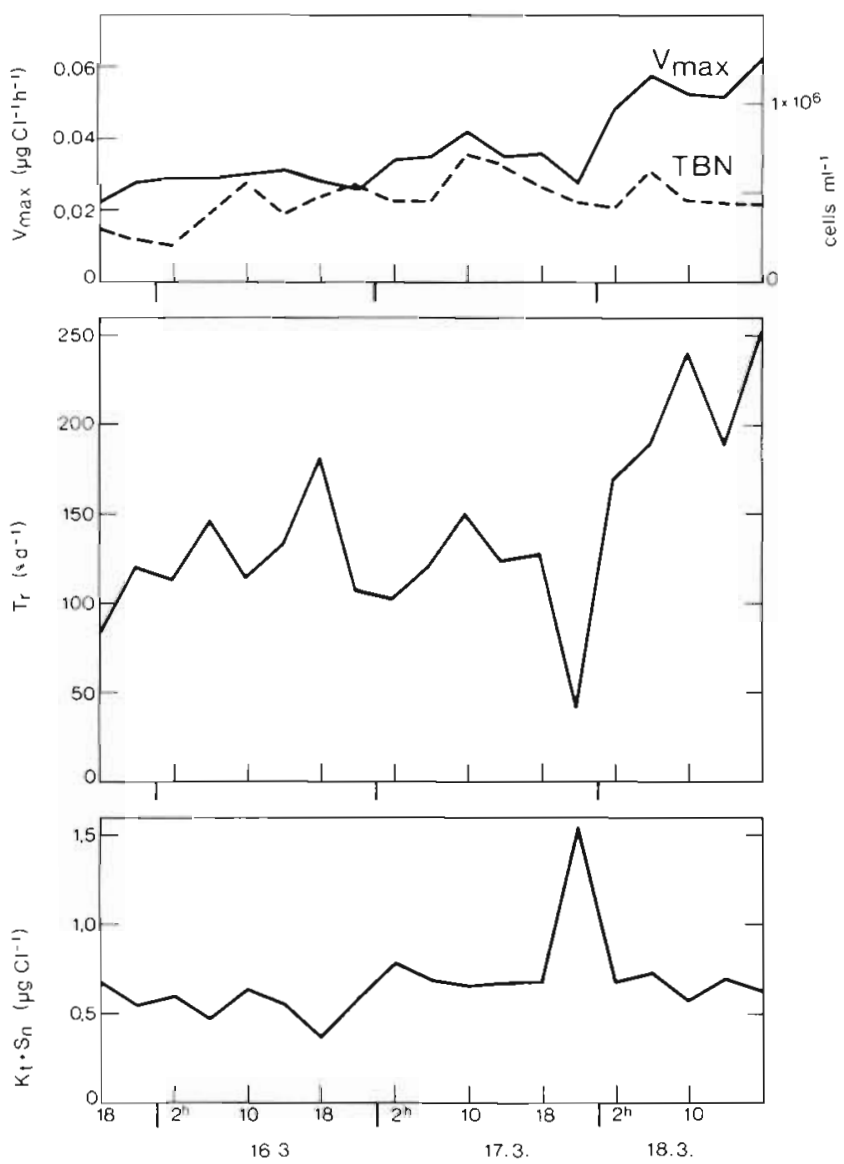

Fig. 5. Short-term fluctuations of microbiological parameters in March. Parameters as indicated in Fig. 4
In September, the mean $V_{\text {max }}$ value was even higher than in June, whereas short-term variations were much less pronounced (Fig. 7). A remarkable decrease occurred around the middle of the study period, which was also observed in the $T_{r}$ and TBN values. $V_{\max }$ and TBN were significantly correlated ( $\mathrm{p}<5 \%$ ). There was also a nearly exact parallelism between $V_{\max }$ and the chlorophyll a concentrations but only during the second half of the period (Osterroht et al. 1985a, b).
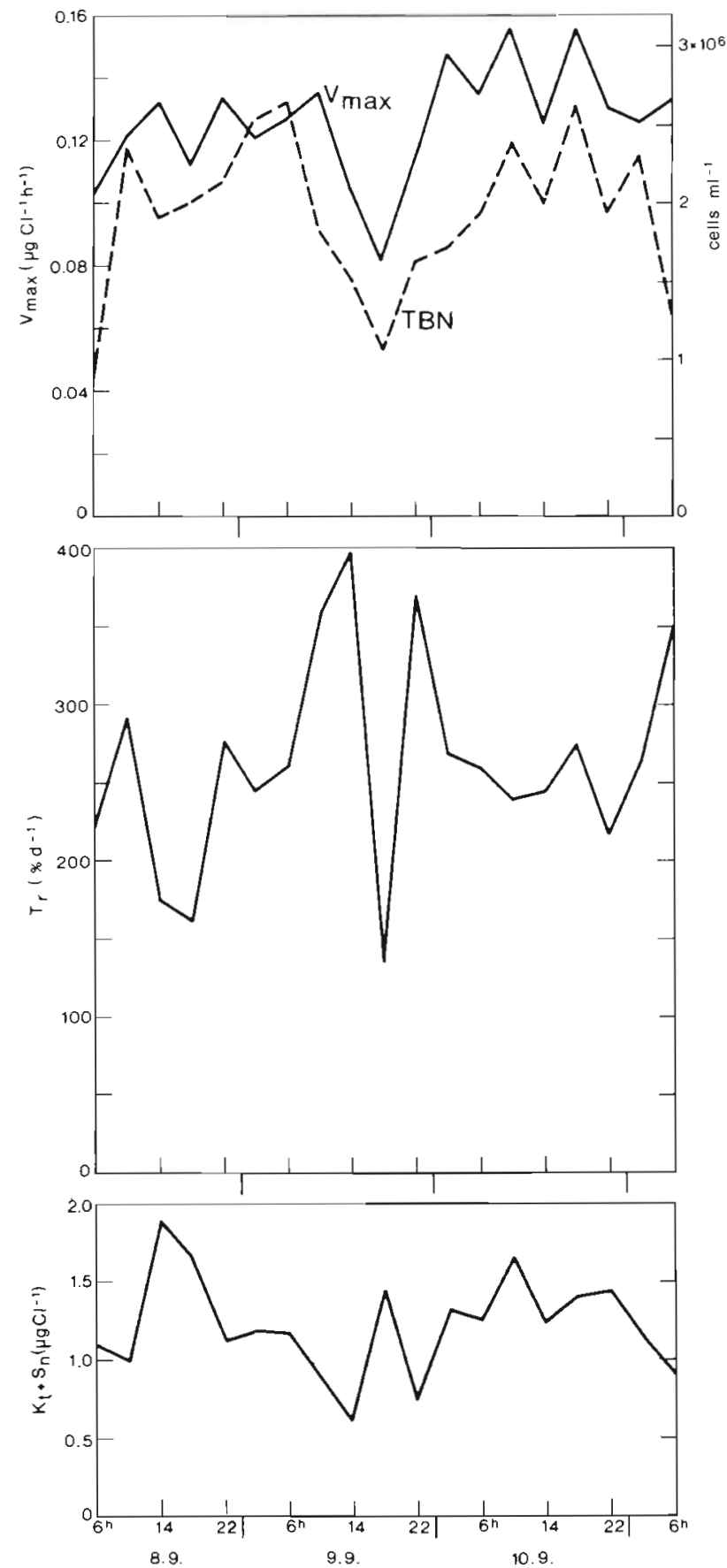

Fig. 6. Short-term fluctuations of microbial parameters in June. Parameters as indicated in Fig. 4 

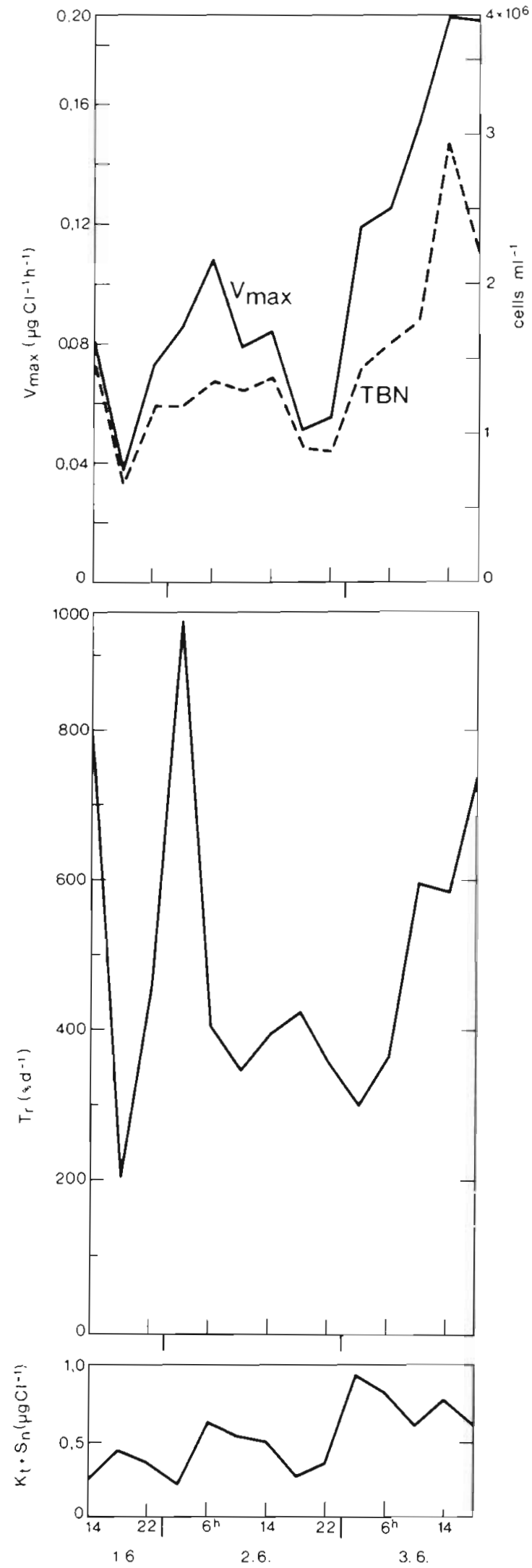

Fig. 7 Short-term fluctuations of microbial parameters in September. Parameters as indicated in Fig. 4

\section{DISCUSSION}

The results of the investigation showed marked seasonal trends. Bacterial activity (measured as maximum uptake velocity of glucose), in particular, was directly related to temperature (Fig. 3). Total number of bacteria, as well as turnover rate of glucose, clearly increased during the warmer seasons. Direct relations to temperature, however, were not found.

Lowest values for total number of bacteria (TBN) were observed in March. In spite of the spring bloom of phytoplankton, TBN was even lower than during the winter sampling. In June the mean value of bacterial numbers surpassed 3-fold the value in March. For the same period, maximum uptake velocity was 2.8 times higher (Table 1). At first glance, there seems to be a striking parallelism. Since, however, water temperature increased about $10^{\circ} \mathrm{C}$ between the 2 sampling periods, which resulted in an increase in $V_{\max }$ of about 2 according to the $Q_{10}$ rule, the rise should have been much more pronounced. This discrepancy is even more marked comparing March and September stations, when the difference of water temperature was about 14 ${ }^{\circ} \mathrm{C}$. Here a 4.6 -fold increase in TBN was accompanied by only a 3.4 fold rise of $\mathrm{V}_{\max }$. It is obvious therefore, that activity per bacteria cell did not depend on temperature alone.

In Table 1, maximum uptake velocities of glucose per cell are presented. This parameter showed a pronounced increase between January and March of more than an order of magnitude, accompanied only by a small increase in water temperature. It should be stated here that the temperature in January was extremely low (mean value: $-0.3^{\circ} \mathrm{C}$ ), which may have caused the small rise to $+2.2^{\circ} \mathrm{C}$ (mean value) in March to be more important than it seems. It is believed, however, that the increased temperature is only partly responsible for the pronounced increase in activity per cell.

Other factors may be more important. During winter, primary productivity is very low; thus, at least the autochthonous input of labile organic material is very small. As a consequence of low substrate concentration coupled with low temperature, the major part of the bacterial cells exist in an inactive state. This is supported by the results of Hoppe (1977) obtained in the Kiel Bight. Using autoradiographic techniques, he found that during winter only about $5 \%$ of total bacterial cells were active.

During the phytoplankton spring bloom, bacteria will be stimulated by increased input of labile organic material. This material probably exists mostly as low molecular organic weight substances, which are excreted by healthy algal cells. Since it is readily utilizable by bacteria, the increased input is not reflected by an increase in DOC as shown in Table 1. As a response, 
bacterial populations probably developed a much higher percentage of active bacteria (Hoppe 1977) and an increased activity per bacterial cell, which were not yet accompanied by higher cell numbers.

Similar results were obtained during a study performed in May in the western and central part of the Baltic Proper. In the Bornholm Basin, where the phytoplankton spring bloom was at its peak, the $V_{\max }$ of glucose per bacterial cell was about 10 times higher than in the more central part, where the bloom had not yet started (Gocke \& Hoppe 1982b).

Table 1 shows that, during summer and autumn stations, activity per cell declined somewhat compared with the spring station, in spite of elevated temperatures. Since the percentage of active bacteria during this time of the year is quite high (Hope 1977), it could be assumed that the specific activity per active cell has decreased considerably.

Another interesting result of this study was the seasonal variation of turnover rate of glucose. During sampling in January, March and June an almost perfect parallelism between $V_{\max }$ and $T_{r}$ (mean values) was observed. In September, however, instead of an expected turnover rate of about $600 \% \mathrm{~d}^{-1}$, less than half this value was found. The explanation is given by the time course of the parameter $K_{t}+S_{n}$, which in September was more than twice as high as in the foregoing samples. Apparently glucose concentrations had increased considerably; alternatively the affinity of the glucose uptake system had decreased, resulting in a higher $K_{t}$ value. There may also be a combined effect of these 2 variables. A higher value for $K_{t}+S_{n}$ results in a reduction of the turnover rate of the pool of dissolved free glucose.

Concerning short-term variations of the parameters TBN, $V_{\text {max }}$ and $T_{r}$, no distinct diel rhythm was observed. Many workers have dealt with the problem of diel variations of chemical and microbiological variables. The results obtained are inconsistent. Some do not indicate trends at all, whereas others are contradictory insofar as maxima (or minima) of the same variable were found at different times of the day. These may represent local peculiarities of the areas under study or may be simply accidental.

Our own results, in spite of the very pronounced short-term variations, do not show diel fluctuations. The variations observed are presumably caused by hydrographical changes, which are a common feature in the study area. Similar studies in the Kiel Bight and Kiel Fjord also showed a strong influence of hydrography on the variations of microbiological parameters (Gocke 1975, Meyer-Reil et al. 1979). If diel fluctuations existed, these were masked by the fact that, during the study, samples from water bodies with different biological history were taken.
It is clearly shown by our results that if one is interested in the seasonal amplitude of microbiological parameters in transitional areas like the Kiel Bight samples have to be taken at short intervals, otherwise a misleading picture may be obtained.

\section{LITERATURE CITED}

Babenerd, B. (1980). Untersuchungen zur Produktionsbiologie des Planktons in der Kieler Bucht. Dissertation, Universität Kiel

Babenerd, B., Zeitzschel, B. (1985). Trends für eintragsrelevante Faktoren und für die Nährsalzkonzentrationen im Wasser der Kieler Bucht. Ber. Inst. Meeresk. Univ. Kiel. 148: $1-48$

Ehrhardt, M., Wenck, A. (1984). Wind pattern and hydrogen sulfide in shallow waters of the Western Baltic Sea, a cause and effect relationship? Meeresforsch. 30: 101-110

Elder, L. (1979). Recommendations on methods for marine biological studies in the Baltic Sea, phytoplankton and chlorophyll. The Baltic Marine Biologists, Publication No. 5

Gocke, K. (1975). Studies on short-term variations of heterotrophic activity in the Kiel Fjord. Mar. Biol. 33: 49-55

Gocke, K. (1977). Heterotrophic activity. In: Rheinheimer, G. (ed.) Microbial ecology of a brackish water environment. Springer Verlag, Berlin, p. 198-222

Gocke, K., Hoppe, H.-G. (1982a). Entwicklung von Bakterienzahl und -aktivität während einer Frühjahrsblüte des Phytoplanktons in der Ostsee. Botanica mar. 25: 295-303

Gocke, K., Hoppe, H.-G. (1982b). Regionalverteilung der Bakterienzahl und -aktivität in der mittleren Ostsee. Botanica mar. 25: 381-389

Hoppe, H.-G. (1977). Analysis of actively metabolizing bacterial populations with the autoradiographic method. In: Rheinheimer, G. (ed.) Microbial ecology of a brackish water environment. Springer Verlag, Berlín, p. 179-197

Kändler, R. (1951). Der Einfluß der Wetterlage auf die Salzgehaltsschichtung im Übergangsgebiet zwischen Nordund Ostsee. Dt. hydrogr. Z. 4: 150-160

Lenz, J. (1977). Hydrographic conditions. In: Rheinheimer, G (ed.) Microbial ecology of a brackish water environment. Springer Verlag, Berlin, p. 12-25

Liebezeit, G. (1980). Chlorophyll a in marine phytoplankton: separation by HPLC and specific fluorometric detection. J. high Resolut. Chromatogr. Comm. 3: 531-533

Meyer-Reil, L.-A., Bölter, M., Liebezeit, G., Schramm, W. (1979). Short-term variations in microbial and chemical parameters. Mar. Ecol. Progr. Ser. 1: 1-6

Osterroht, C., Wenck, A., Kremling, K., Gocke, K. (1985a). - Concentration of dissolved organic copper in relation to other chemical and biological parameters in coastal Baltic waters. Mar. Ecol. Prog. Ser. 22: 273-279

Osterroht, C., Wenck, A., Kremling, K., Gocke, K. (1985b). Chemical, planktological and microbiological investigations at an anchor station in Kiel Bight during 1981/82. Ber. Inst. Meeresk. Univ. Kiel. 141: 1-15

Rheinheimer, G., (1985). Mikrobiologie der Gewässer. VEB Gustav Fischer Verlag, Jena

Schreurs, W. (1978). Automated colorimetric method for the determination of dissolved organic carbon in sea water by UV-destruction. Hydrobiol. Bull. 12: 137-142

Strathmann, R. R. (1967). Estimating the organic carbon content of phytoplankton from cell volume or plasma volume. Limnol. Oceanogr. 12: 411-418

Wright, R. T., Hobbie, J. E. (1966). Use of glucose and acetate 
by bacteria and algae in aquantic ecosystems. Ecology 47 $447-464$

Zimmermann, R. (1977). Estimation of bacterial number and biomass by epifluorescence microscopy and scanning pelectron microscopy. In: Rheinheimer, G. (ed.) Microbial ecology of a brackish water environment. Springer Verlag, Berlin, p. 103-120

Zimmermann, R., Meyer-Reil, L.-A. (1974). A new method for fluorescence staining of bacterial populations on membrane filters. Kieler Meeresforsch. (Sonderh.) 30: 24-27

This article was submitted to the editor; it was accepted for printing on August 4, 1987 